\title{
PENGGUNAAN MODEL PEMBELAJARAN KOOPERATIF TIPE TEAM PAIR SOLO BERBANTUAN SOFTWARE GEOGEBRA UNTUK MENINGKATKAN HASIL BELAJAR SISWA PADA MATERI LINGKARAN
}

\author{
Christina M. Laamena', Magy Gaspersz ${ }^{2}$, Pieter Z. Tupamahu \\ ${ }^{1,2,3}$ Prodi Pendidikan Matematika Fakultas Keguruan dan Ilmu Pendidikn, Universitas Pattimura \\ Jalan Ir. M. Putuhena, Kampus Unpatti, Poka, Ambon, Indonesia \\ e-mail: ${ }^{1}$ christinmath18@gmail.com;
}

\begin{abstract}
Abstrak
Penelitian ini bertujuan untuk meningkatkan hasil belajar siswa kelas VIII SMP Negeri 6 Ambon pada materi lingkaran menggunakan model pembelajaran kooperatif tipe Team Pair Solo berbantuan software geogebra. Subjek pada penelitian ini adalah siswa kelas VIII-Sains SMP Negeri 6 Ambon, yang berjumlah 28 siswa. Jenis Penelitian ini adalah Penelitian Tindakan Kelas (PTK). Penelitian ini terdiri dari dua siklus dengan setiap siklus terdiri dari 2 pertemuan. Teknik pengumpulan data dalam penelitian ini diperoleh melalui observasi dan tes akhir setiap siklus. Hasil belajar siswa dari siklus I ke siklus II mengalami kenaikan sebesar 25\%. Berdasarkan hasil yang diperoleh, maka dapat disimpulkan bahwa hasil belajar siswa pada materi lingkaran dapat ditingkatkan menggunakan model pembelajaran kooperatif tipe Team Pair Solo berbantuan software geogebra di kelas VIII SMP Negeri 6 Ambon
\end{abstract}

Kata Kunci: model pembelajaran tipe team pair solo, lingkaran, software geogebra

\section{THE USE OF COOPERATIVE LEARNING MODEL TEAM PAIR SOLO ASSISTED GEOGEBRA TO IMPROVE STUDENT LEARNING OUTCOMES ON CIRCLE MATERIAL}

\begin{abstract}
This study aims to improve the learning outcomes of grade VII students of SMP Negeri 6 Ambon in circle material by using the Team Pair Solo type cooperative model with the help of the Geogebra Software. The subjects of this study were students of class VIII-Science of SMP Negeri 6 Ambon, amounting to 28 students. This type of research was Classroom Action Research (CAR). This study was conducted in two cycles with every cycles suddenly from four meetings. Data in this study were collected through observation and test sheets. The findings in this study indicate that the final test results from cycle I to cycle II increased by $25 \%$. Based on the results of this study it can be concluded that student learning outcomes in circle material can be improved with Team Pair Solo learning models assisted by Software Geogebra Software in class VIII of SMP Negeri 6 Ambon
\end{abstract}

Keywords: learning model type team pair solo, circle, geogebra software

\section{Pendahuluan}

Kemajuan teknologi pada abad ke-21 turut mempengaruhi segala aspek kehidupan manusia, tak terkecuali dalam aspek pendidikan. Teknologi yang berkembang pesat, memaksa dunia pendidikan harus melakukan inovasi yang positif untuk kemajuan pendidikan dan sekolah. Pendidikan adalah suatu proses pelatihan dan pengajaran yang tidak memandang batasan usia maupun keberadaan, dengan tujuan memberikan pengetahuan dan mengembangkan keterampilan. Hal ini membuat manusia harus lebih relevan dalam menggunakan kemajuan teknologi dalam dunia pendidikan.

Pemanfaatan teknologi dalam proses pembelajaran terutama teknologi komputer mempermudah guru untuk menjelaskan materi pembelajaran yang bersifat abstrak dan jauh dari 
penalaran siswa menjadi mudah untuk dipahami. Melalui bantuan teknologi, guru akan lebih mudah melakukan simulasi pembelajaran dari yang abstrak menjadi nyata.

Pendidikan matematika merupakan salah satu dari sekian banyak bidang ilmu pendidikan yang dipelajari dan merupakan sarana pendukung agar tercapai pembangunan yang berkualitas. Menurut Aditya (2018: 65), peran matematika pada bidang pendidikan sangatlah penting, karena matematika diajarkan dari jenjang SD untuk membekali mereka dengan kemampuan berpikir logis, analitis, sistematis, kritis, dan kreatif. Semakin tinggi jenjang pendidikan yang ditempuh maka ilmu pengetahuan matematika yang diperoleh juga semakin berkembang.. Materi matematika cendrung bersifat abstrak dan dinilai monoton sehingga diperlukan alat atau teknologi yang dapat membantu pengkomunikasikan materi dan memudahkan siswa dalam menerima informasi pada proses pembelajaran.

Salah satu materi matematika yang diajarkan pada tingkat Sekolah Menengah Pertama (SMP) adalah lingkaran. Nuroniah (Lestari dkk, 2016: 374) menyatakan bahwa kesulitan siswa dalam mempelajari matematika khususnya geometri terutama pada materi pokok lingkaran. Hal ini menimbulkan terjadinya berbagai kesalahan dalam penyelesaiannya.

Siswa kurang memahami dan kurang mampu mengaitkan materi terdahulu dengan materi selanjutnya seperti materi bilangan bulat, dan perbandingan serta phytagoras. Dengan demikian, siswa kesulitan dalam mempelajari materi-materi yang berkaitan dengan lingkaran seperti tabung dan bola (Astuti (Pulungan, 2018: 6)).

Menurut Sari (2016: 108), ada beberapa faktor yang membuat siswa salah dalam menyelesaikan soal terkait dengan materi lingkaran yaitu. (1) Siswa sekedar menghafal rumus sehingga kurang memahami konsep yang berkaitan dengan rumus-rumus pada linglkaran. (2) Siswa banyak bingung mengerjakan soal yang bentuknya berbeda. (3) Siswa kurang memahami soal. (4) siswa tidak dapat memahami definisi diameter dan tembereng.

Berdasarkan hasil wawancara tidak terstruktur dan observasi terhadap pelaksanaan pembelajaran matematika di SMP Negeri 6 Ambon, diperoleh informasi bahwa sebagian besar siswa tidak mengetahui secara keseluruhan unsur-unsur lingkaran dan cenderung salah dalam menyelesaikan soal yang terkait dengan materi lingkaran. Masalah di atas mengakibatkan hasil belajar siswa kelas VIII SMP Negeri 6 Ambon pada materi lingkaran belum mencapai Kriteria Ketuntasan Minimal (KKM), yaitu 72.

Hasil observasi terhadap proses pembelajaran, menunjukan bahwa guru hanya menyampaikan materi kepada siswa, sedangkan tugas dari siswa hanyalah mendengarkan penyampaian materi oleh guru dan mencatat. Sehubungan dengan permasalahan tersebut, maka diperlukan model pembelajaran yang memberikan kesempatan kepada siswa untuk memahami konsep-konsep yang diajarkan dan mengkomunikasikan ide atau alasan, sehingga salah satu model pembelajaran yang digunakan adalah model pembelajaran kooperatif yang mengutamakan belajar kelompok.

Terdapat banyak tipe dalam model pembelajaran kooperatif salah satunya Team Pair Solo. Menurut Warsono dan Hariyanto (2013: 233), model Team Pair Solo membuat siswa terlibat secara langsung dalam proses pembelajaran sekaligus mendorong siswa untuk berpikir dalam kelompok kemudian berpikir secara analisis mandiri. Model ini didesain untuk mengontrol siswa menyelesaikan masalah yang pada awalnya belum dipahami oleh siswa. Model pembelajaran tipe Team Pair Solo dapat membantu siswa memahami suatu konsep materi secara bertahap, sehingga model Team Pair Solo dapat digunakan untuk proses belajar mengajar terkhususnya pada materi lingkaran.

Pada tahap team (kelompok) siswa bersama teman kelompoknya mendiskusikan bahkan saling bertukar informasi terkait dengan materi lingkaran yang diajarkan guru. Tahap pair (pasangan), siswa secara berpasangan mengerjakan masalah yang diberikan guru setelah itu mempresentasikan hasil kerja kepada pasangan-pasangan lain yang diharapkan dapat meningkatkan pemahaman siswa pada materi lingkaran. Tahap terakhir yaitu solo (individu) adalah pemberian evaluasi kepada siswa secara individu untuk mengetahui sejauh mana tingkat pemahaman siswa pada materi lingkaran.

Selain model pembelajaran yang bersifat kooperatif, guru juga dapat menggunakan komputer sebagai media pembelajaran yang sangat mendukung dalam rangka penyelenggaraan pendidikan yang efektif dan efisien. Banyak program komputter yang telah diciptakan pada era industry 4.0 ini dan digunakan sebagai media pembelajaran, salah satu program komputer yang dapat digunakan sebagai media pembelajaran matematika adalah software geogebra. Menurut Hendriana (2017: 128), geogebra adalah salah 
satu software matematika yang didukung dengan lengkap untuk semua aspek bidang matematika mulai dari aritmatika, geometri, aljabar dan kalkulus, dengan alat-alat yang memungkinkan berkerja dengan titik, vektor, garis, irisan kerucut dan masih banyak lagi.

Pemanfaatan geogebra sebagai media pembelajaran dapat menghasilkan lukisan-lukisan geometri dengan cepat dan teliti bahkan yang rumit. Terkait dengan manfaat tersebut, maka penggunaan software geogebra untuk materi lingkaran sangatlah tepat mengingat untuk menggambar sebuah lingkaran harus memiliki keakuratan yang tepat, selain itu juga dapat mempersingkat waktu guru dalam menggambar lingkaran maupun unsur-unsurnya secara manual atau menggunakan alat jangka.

Software geogebra dapat dimanfaatkan guru sebagai bahan evaluasi atau perbandingan terhadap hasil kerja siswa, karena dalam software geogebra terdapat tool (alat) untuk menghitung panjang garis atau luas daerah suatu lingkaran. Dengan demikian salah satu solusi yang dapat membantu siswa dalam proses pembelajaran terkait dengan konsep geometri terkhususnya materi lingkaran adalah dengan menerapkan pembelajaran menggunakan software geogebra.

Model Pembelajaran Kooperatif Tipe Team Pair Solo berbantuan Software Geogebra pada materi lingkaran dilaksanakan dalam tiga tahapan yaitu.(1) Tahap Team, guru menyajikan dan membahas konsep dasar lingkaran kepada para siswa dengan menggunakan software geogebra. (2) Tahap Pair, siswa secara berpasangan mengerjakan lembar kerja yang diberikan menggunakan perhitungan manual maupun menggunakan software geogebra. (3) Tahap Solo, siswa bekerja secara individu untuk menyelesaikan soal tugas yang terkait dengan materi lingkaran.

Berdasarkan latar belakang yang telah diuraikan, maka penulis tertarik untuk membuat penelitian dengan judul : "Peningkatan Hasil Belajar Siswa Pada Materi Lingkaran Melalui Model Pembelajaran Kooperatif Tipe Team Pair Solo Berbantuan Software Geogebra Di Kelas VIII SMP Negeri 6 Ambon".

\section{Metode Penelitian}

\subsection{Jenis Penelitian}

Penelitian ini merupakan Penelitian Tindakan Kelas (PTK) dengan memiliki empat tahapan yaitu perencanaan (planning), pelaksanaan (acting), pengamatan (observating), dan refleksi (reflecting).

\section{Subjek Penelitian}

Subjek pada penelitian ini adalah siswa kelas VIII-Sains SMP Negeri 6 Ambon yang berjumlah 28 siswa.

\subsection{Prosedur Penelitian}

Penelitian ini terdiri dari dua siklus dengan tiap siklus terdiri dari dua pertemuan. Gambaran umum yang dilakukan setiap siklus adalah perencanaan, pelaksanaan, observasi dan refleksi.

\subsection{Teknik Pengumpulan Data}

Teknik Pengumpulan data pada penelitian ini adalah sebagai berikut.

a. Tes hasil belajar pada tiap akhir siklus.

b. Lembar observasi aktivitas siswa dan guru selama proses pelaksanaan tindakan.

\subsection{Teknik Analisis Data}

Data tentang aktivitas belajara siswa dianalisis secara kualitatif. Aktivitas dalam analisis data kualitatif yaitu reduksi data, penyajian data dan penarikan kesimpulan. Sedangkan data hasil belajar siswa dianalisis secara kuantitatif.

Dari nilai yang diperoleh, kemudia di klasifikasikan tingkat ketuntasan siswa menurut Kriteria Ketuntasan Minimal (KKM) yang telah ditetapkan oleh SMP Negeri 6 Ambon, yaitu.

Tabel 1. Kriteria Ketuntasan Minimal (KKM)

\begin{tabular}{|c|c|}
\hline Nilai & Keterangan \\
\hline$\geq 72$ & Tuntas \\
\hline$<72$ & Belum Tuntas \\
\hline
\end{tabular}

Secara klasikal untuk menghitung presentasi ketuntasan siswa terhadap materi pelajaran menggunakan rumus.

$$
\begin{aligned}
& \text { Persentasi } \\
& =\frac{\text { Jumlah siswa yang mencapai KKM }}{\text { Jumlah seluruh siswa }} \times 100 \%
\end{aligned}
$$

Suryosubroto (2009: 77) mengemukakan bahwa syarat suatu pembelajaran dikatakan tuntas secara individu maupun klasikal adalah seorang siswa dikatakan tuntas belajar jika siswa tersebut mencapai skor minimal $65 \%$. Berdasarkan hal inilah dalam penelitian ini suatu kelas dikatakan tuntas dalam proses pembelajaran jika $65 \%$ dari jumlah seluruh siswa mencapai KKM yaitu lebih dari atau sama dengan $72(\geq 72)$. 


\section{Hasil dan Pembahasan}

\subsection{Hasil}

Pada kegiatan pendahuluan, peneliti bersama guru sepakat untuk memberikan pengenalan terkait dengan penggunaan software geogebra terkhususnya untuk materi lingkaran. Pengenalan ini dimaksudkan agar pada proses penelitian menggunakan software geogebra, siswa tidak mengalami kesulitan dalam penggunaannya serta proses penelitian dapat berjalan dengan baik dan lancer. Pembagian kelompok pada penelitian ini didasarkan pada pengalaman mengajar yang dilihat dari kemampuan siswa dalam kesehariannya di dalam kelas. Hal ini bertujuan agar siswa yang ada pada setiap kelompok bersifat heterogen.

Setelah melakukan kegiatan pendahuluan selanjutnya adalah pelaksanaan siklus I. Pada tahap perencanaan guru menyiapkan perangkat pembelajaran seperti RPP, LKS, soal pada tahapan solo dan bahan ajar menggunakan software geoggebra, selain itu ada juga instrument penelitian seperti lembar observasi aktivitas guru dan siswa serta soal tes akhir siklus. Pada tahap pelaksanaan guru melaksanakan kegiatan pembelajaran sesuai dengan RPP yang telah disiapkan dengan berbantuan software geogebra. Pada siklus I diperoleh hasil belajar seperti pada tabel 2.

Tabel 2. Hasil Belajar Siswa Siklus I

\begin{tabular}{|c|c|c|c|}
\hline KKM & Frekuensi & $\begin{array}{c}\text { Presentasi } \\
(\boldsymbol{\%})\end{array}$ & Keterangan \\
\hline$\geq 72$ & 15 & 53,57 & Tuntas \\
\hline$<72$ & 13 & 46,43 & $\begin{array}{c}\text { Belum } \\
\text { Tuntas }\end{array}$ \\
\hline Jumlah & 28 & 100 & \\
\hline
\end{tabular}

Dari hasil tersebut diperoleh presentasi ketuntasan belajar matematika sebesar 53,57\%. Hal ini belum sesuai dengan syarat ketuntasan belajar yaitu $>65 \%$. Oleh karena itu, perlu dilakukan refleksi dan tindakan pada siklus II.

Pada siklus II siswa yang tuntas belajar sebanyak 22 siswa dengan presentasi 78,57\% dan siswa yang belum tuntas sebanyak 6 siswa dengan presentasi 21,43\%. Hasil akhir siklus II disajikan dalam table 3 .

Tabel 2. Hasil Belajar Siswa Siklus II

\begin{tabular}{|c|c|c|c|}
\hline KKM & Frekuensi & $\begin{array}{c}\text { Presentasi } \\
(\mathbf{\%})\end{array}$ & Keterangan \\
\hline$\geq 72$ & 22 & 78,57 & Tuntas \\
\hline$<72$ & 6 & 21,43 & $\begin{array}{c}\text { Belum } \\
\text { Tuntas }\end{array}$ \\
\hline Jumlah & 28 & 100 & \\
\hline
\end{tabular}

Pada tabel 3 terlihar bahwa hasil tes akhir siklus II menunjukan adanya peningkatan sehingga sebagian besar siswa telah mencapai standar ketuntasan minimal, yaitu $65 \%$ siswa telah mencapai nilai 72. Berdasarkan hasil tes akhir siklus II ini, maka peneliti, guru yang mengajar, serta guru yang menjadi observer bersama 2 teman mahasiswa menilai bahwa pelaksanaan tindakan perbaikan telah berhasil dilaksanakan, sehingga kami sepakat untuk tidak melanjutkan tes siklus selanjutnya.

Adapun peningkatan hasil belajar yang terjadi dari siklus I sampai ke siklus II pada penelitian ini, disajikan dalam diagram berikut.

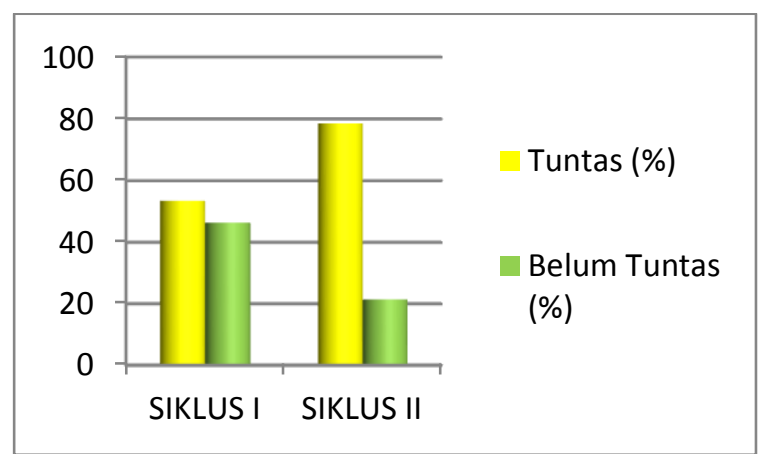

Gambar 1. Diagram Persentasi Ketuntasan Belajar

\subsection{Pembahasan}

Siklus I

Pelaksanaan pembelajaran pada siklus I terdiri dari 2 pertemuan dengan pertemuan pertama membahas tentang pengertian lingkaran, unsur-unsur lingkaran dan keliling lingkaran, sedangkan pada pertemuan kedua membahas tentang luas daerah lingkaran. Setelah diadakan tindakan pada siklus I diperoleh data hasil tes akhir pada siklus I. Data tersebut menunjukan bahwa 13 siswa atau sebesar 46,43\% belum mencapai KKM. Hal ini dikarenakan pada proses pembelajaran Team Pair Solo belum diterapkan dengan maksimal.

Berdasarkan hasil refleksi pada siklus I, terdapat kekurangan dan kelemahan yang berkaitan dengan proses pembelajaran menyangkut aktivitas guru maupun siswa, yaitu penguasaan dan pengelolaan kelas yang kurang dari guru, sehingga memberikan kesempatan bagi siswa untuk bercerita dan mengganggu teman. Menurut Rusman (2012: 77), salah satu komponen mengelola kelas dengan baik adalah mengembalikan kondisi belajar yang optimal agar tujuan dari pembelajaran tersebut dapat dicapai dengan baik.

Kelemahan lainnya yaitu, siswa kurang aktif dalam kegiatan kelompok maupun kurang berinteraksi dalam diskusi bersama pasangan. Menuru Ratumanan (2015: 151), aktivitas siswa yang baik antara lain mengikuti penjelasan guru secara aktif, bekerja sama 
menyelesaikan tugas-tugas kelompok, memberikan penjelasan kepada teman kelompoknya, mendorong kelompok untuk berpartisipasi secara aktif, berdiskusi dan sebagainya. Hal ini berimplikasi pada keberhasilan suatu proses pembelajaran yang mengharuskan siswa untuk tidak saja aktif pada saat bekerja secara individu (solo) tetapi juga secara berpasangan (pair) dan kelompok (team).

Pada siklus I juga, masih ada siswa yang kesulitan dalam menggunakan software geogebra walaupun sudah diberikan pengenalan terkait software geogebra sebelum proses pembelajaran pada siklus I dilaksanakan. Menurut Rohani (2010: 193), siswa yang memasuki situasi baru secara mendadak sering menimbulkan tekanan psikologis karena situasi yang lama sering membayangi mereka. Dengan demikian situasi belajar mengajar yang baru tersebut membuat proses pembelajaran terhadap siswa agak lambat dan terasa sulit.

Secara umum pada siklus I belum menunjukan adanya peningkatan hasil belajar siswa, serta keberhasilan guru dalam menerapkan model pembelajaran kooperatif tipe Team Pair Solo berbantuan software geogebra. Beberapa masalah di atas membuat proses pembelajaran kurang berjalan dengan baik dan siswa kesulitan dalam menyelesaikan soal tes akhir siklus I, sehingga hasil belajar siklus I belum memenugi KKM. Oleh sebab itu, perlu dilanjutkan pada siklus berikutnya sebagai tindakan perbaikan dan solusi yang terjadi pada siklus I.

\section{Siklus II}

Pelaksanaan tindakan pada siklus II terdiri dari 2 pertemuan. Pada pertemuan pertama membahas tentang sudut pusat, sudut keliling, dan panjang busur, sedangkan pertemuan kedua membahas tentang luas tembereng dan luas juring. Setelah diadakan tindakan pada siklus II diperoleh data hasil tes akhir pada siklus II. Data tersebut menunjukan bahwa 22 siswa atau sebesar 78,8\% sudah mencapai KKM. Pelaksanaan pada siklus II pun sudah sesuai dengan yang direncanakan, sehingga dapat disimpulkan perbaikan dari siklus I ke siklus II berhasil.

Pada pelaksanaan tindakan siklus II, guru sudah bisa memotivasi siswa untuk berpartisipasi aktif dalam proses pembelajaran, sehingga siswa aktif dalam proses pembelajaran, sehingga siswa aktif dalam proses pembelajaran. Guru juga dapat mengelola kelas dengan baik. Pada saat diskusi secara berpasangan maupun pengerjaan soal tes secara individu guru berkeliling membimbing siswa.

Selain itu, siswa sudah bisa bekerja sama di dalam kelompok (team) untuk menyelesaikan masalah yang ditanyakan guru sambil melakukan proses diskusi dengan baik. Pada tahap berpasangan (pair) seluruh siswa dapat saling bertukar pikiran untuk menyelesaikan LKS yang diberikan guru. Siswa aktif dan sangat serius dalam melakukan diskusi kelompok maupun pasangan, sehingga perilaku-perilaku siswa yang tidak bagus atau relevan tidak terlihat pada siklus II.

Siswa juga sudah tidak mengalami kesulitan dalam menggunakan software geogebra, sehingga dapat dengan mudah menggunakan software geogebra untuk pemvisualisasian dan membandingkan hasil perhitungan. Akhir dari proses pembelajaran, sebagian besar siswa sudah mampu untuk mengerjakan soal tes secara individu (solo) dan mendapatkan nilai yang mencukupi bahkan melebihi kriteria ketuntasan minimal.

Berdasarkan hasil tes akhir siklus I dan siklus II, menunjukan perubahan yang lebih baik dari siklus I ke siklus II. Berdasarkan hasil yang diperoleh, dan adanya peningkatan pada siklus II, maka dapat disimpulkan bahwa model pembelajaran kooperatif tipe Team Pair Solo berbantuan software geogebra yang telah diterapkan oleh guru di kelas, telah dilaksanakan dengan baik dan pelaksanaan tindakan telah dillakukan dengan baik. Hal ini menunjukan bahwa hipotesis tindakan telah tercapai, yaitu ada peningkatan hasil belajar siswa pada materi lingkaran dengan model pembelajaran kooperatif tipe Team Pair Solo berbantuan software geogebra di kelas VIII SMP Negeri 6 Ambon.

\section{Kesimpulan}

Berdasarkan hasil dan pembahasan yang telah dipaparkan pada bab IV, maka dapat disimpulkan bahwa dengan menggunakan model pembelajaran kooperatif tipe team pair solo berbantuan software geogebra pada materi lingkaran, maka hasil belajar siswa kelas VIII SMP Negeri 6 Ambon dapat ditingkatkan. Hal ini terlihat dari hasil tes siklus I yang memperoleh Kriteria Ketuntasan Minimal (KKM) atau memperoleh nilai 72 sebanyak 15 siswa dengan presentasi 53,57\%. Kemudian pada siklus II siswa yang memperoleh Kriteria Ketuntasan Minimal (KKM) atau siswa yang memperoleh nilai 72 sebanyak 22 siswa dengan presentasi $78,57 \%$. Berdasarkan ketuntasan pada siklus I dan siklus II, maka terjadi peningkatan yang terjadi dari siklus I ke siklus II sebesar $25 \%$.

\section{Daftar Pustaka}

Aditya, T, P. 2018. Pengembangan Media Pembelajaran Matematika Berbasis WEB Pada MAteri Lingkaran Bagi Siswa Kelas VIII. Jurnal 
Matematika, Statistika dan Komputasi, Volume 15 Nomor 1, Hal 64-74, http://journal.unhas.ac.id/index.php/jmsk diakses pada tanggal 3 mei 2019

Hendriana, B. 2017. Aplikasi Komputer Mengenal Software Matematika. Jakarta

Lestari dkk. 2016. Analisis Kesalahan Siswa Kelas IX Dalam Menyelesaikan Soal Cerita Keliling dan Luas Lingkaran di SMP AL-Azhar Palu. Jurnal Elektronik Pendidikan Matematika Tadulako, Volume 03 Nomor 04, http://jurnal.untad.ac.id, diakses pada tanggal 2 April 2019

Pulungan, N, K. 2018. Perbedaan Hasil Belajar Siswa Yang Diajarkan Dengan Model Pembelajaran Project Based Larning (PjBL) dan Konvensional Pada Pokok Bahasan Lingkaran Kelas VIII SMP N 3 Tanjung Morawa. Medan. (Skripsi). http://repository.uinsu.ac.id . diakses pada tanggal 3 Mei 2019

Ratumanan, G. T. 2015. Inovasi Pembelajaran (Mengembangkan Kompetensi Peserta Didik Secara Optimal). Yogyakarta: Penerbit Ombak

Rohani. 2010. Pengelolahan Pengajaran. Jakarta: PT Rineka Cipta

Rusman. 2012. Belajar dan Pembelajaran Berbasis Komputer. Bandung: Penerbit Alfabeta

Sari, K, E. 2016. Analisis Kesalahan Siswa Dalam Menyelesaikan Soal Matematika Pada Pokok Bahasan Lingkaran Kelas VIII B SMP Kanisius Kalasan Yogyakarta. Yogyakarta. (Skripsi). http://repository.usd.ac.id, diakses pada tanggal 3 Mei 2019

Suryosubroto. 2009. Proses Belajar Mengajar Di Sekolah. Jakarta: Rineka Cipta

Warsono dan Hariyanto. 2013. Pembelajaran Aktif. Bandung: Remaja Rosdakarya 